\title{
ASEAN Moslem Community as Track-9 on Multitrack Diplomacy for The Conflict Resolution in Southeast Asia Region
}

\section{Tonny Dian Effendi}

Department of International Relations, University of Muhammadiyah Malang kampus Telogo Mas, Malang, 65144

Email: tonny dian@yahoo.com

\section{Abstrak}

Komunitas ASEAN 2015 masih membutuhkan banyak persiapan untuk pelaksanaannya. Bangsa Asia Tenggara harus mempersiapkan perubahan cara pandang untuk memahami organisasi regional. Komunitas epistemik memiliki peranan signifikan dalam membuat jaringan dan bekerjasama dalam bidang mereka dan membuat efek spillover ke publik. Komunitas Muslim ASEAN merupakan salah satu ide yang dapat mendukung komunitas pada 2015. Organisasi ini tidak hanya membangun jaringan untuk kerjasama, namun juga akan berkontribusi dalam resolusi konflik yang berhubungan dengan isu muslim di wilayah ini. Komunitas ini akan memainkan peranan sebagai salah satu diplomasi multitrack untuk resolusi konflik. Sebagai Organisasi non-pemerintahan, komunitas ini akan fleksibel pada kegiatannya dan lebih mudah diterima oleh masyarakat. Akan tetapi harus mempertimbangkan sebagai komunitas netral pada beberapa konflik atau mereka akan kehilangan kredibilitas.

Kata kunci : diplomasi multitract, resolusi konflik, masyarakat muslim, ASEAN

\section{Abstract}

ASEAN Community 2015 still needs many preparations for its implementation. Southeast Asian peoples should prepare their change of mind to view their regional organization. The epistemic community had significant roles to creating network and work together inside their fields and make spillover effect to public. ASEAN Moslem Community is one of the ideas which can support the community on 2015. This organization is not only establishing a network for cooperation, but also it will contribute for conflict resolution in this region relate with moslem issues. This community will play roles as one of multitrack diplomacy for conflict resolution. As Non Governmental organization, this community will have flexible on its activities and relatively can be accepted by the people. But, it should to consider as a neutral community in some conflict or it will lose its credibility. Keywords: multitract diplomacy, conflict resolution, Moslem community, ASEAN

\section{INTRODUCTION}

In 2009, ASEAN leaders was meet in Thailand to discussing the growth and future plan of ASEAN. From this meeting, the ASEAN leaders aggreed to create specific ways to establishing ASEAN vision in 2020. Many programs was launched. As we know that almost five dekade, ASEAN has been strugle on the international environtment change. ASEAN has successfull to maintain cooperation and stability in the region. So, ASEAN tries to make a good point by developing futuristic and ideal mision in 2020.

ASEAN vision in 2020 is establishing Southeast Asia region as open, peaceful, stable, wealthy and harmony, united by the cooperation in the democratic environment, integrated development on economic growth, respectfull each other, united with the history and cultural heritage and all of them are united in the one 
regional identity (ASEAN Secretariat, $2010: 1$ ).

On Bali Concord II, the ASEAN leaders aggreed that in the implementation of ASEAN vision 2020, it is need to real actions by establishing three pillars of ASEAN Community. They are ASEAN PoliticalSecurity Community, ASEAN Economic Community and ASEAN Socio-Cultural Community. These three pillars may enhanching the preparation for ASEAN vision 2020.

Three years after the declaration for the Roadmap for the ASEAN Community, the activities related with the community is stull fluctuative and variative. The ASEAN Economic Community showed good progress. On the way to open the region for the outsider and to enhanching regional econbomic cooperation, some aggreement was signed with its rule. Some of the aggreement has been implemented but another is stil on discussion. In the ASEAN Political-Security Community, there are many meeting and cooperation to enhanche cooperation on politics and security to establishing peacefull Southeast Asia region, including some specific problems like terrorism, transnational crime and human security. Anothe specific problem is about border management among the members. The last pillar, the ASEAN SocioCultural Community also showing some progress but just few publication to educated the people and developing awareness of the community.

The problems that faced related with the activities to ASEAN Community 2015 is on socialization by the members to their people. For the developed country like Singapora, while the access of the information is very easy, so the socialization does not find difficulties, but for developing countries with large population, access of information still be a problem. This problem giving the impact for the progress like few support from the people, low conciusness and all of this based on the problem of the information while the people do not understand well the advantage of the community.

The roles of the academician, businessman and religion group is needed. Their roles can fullfil the empty space that can be provided by the government.
Government has many limitation both on spreading information and eduating the people. So the role of non government group is very needed here. This groups can create a network and cooperation with their partners in another state members. By this way, the people of the members can get enough information because this group can act more flexible than the government. Beside preading the information, these epictemic community can also helping to find some solution for the conflict resolution in Southeast Asia region, of course it is based on their activity focused.

One of the problem in ASEAN is about moslem community and related problems. The problems of moslem community in the region can be generalized on two problems. First, politic related problem. We have known that in some ASEAN countries members like Philipina, Thailand and Myanmar there are some problem related with moslem community that live there. The problem generaly related with their relation with the government.in Philipina and Thailand, the problem of moslem community related with the reparation movement, while in Myanmar it is related with the ommunity relations with the military regime. In other countries member, there are also many problems related with the politics. Second, economic related problem. Population of the moslem community in the region is the largest. But in other hand, they still face the economic problem like poverty. This problem can also be caused of the politic and security problem. Both two main problem should to find the solution.

Related with both problems, so the question is, is ASEAN Community 2015 have mechanism to create the solutions? Of course, I do believe that there are no specific for moslem community resolution in ASEAN but, ASEAN have some regulation and mechanism for the general problem. So, to supporting ASEAN effort to solve many problem inside, it will very good if the moslem epistemic community in ASEAN, have initiative to establish an ASEAN moslem community. It is not to build exclusivity but, it rather than buildthe coordination of the cooperation and network to work together to find the solution of moslem 
community problem in Southeast Asia region.

This article will describe how the ASEAN moslem community can be played as diplomatic tools for conflict resolution. I will use multitrack diplomacy concept which one of the track is the role of religion or peacemaking through faith in action. This article devide on four part. They are backgroud, multitrack diplomacy approach, the problems of moslem in Southeast Asia and the role which can be played by the ASEAN moslem community.

\section{METHODOLOGY}

\section{MULTITRACK DIPLOMACY}

Indeed, diplomacy was known as two general field. They are first-track diplomacy and second-track diplomacy. First-track diplomacy is focus on the diplomatic activities played by the government. This field is also called official diplomacy. The second-track diplomacy is more focused on non government actors. It also called unofficial diplomacy. These diplomacy activity has done by non government actors like businessman, NGOs and even individu (Djelantik, 2008).

On the growth of the diplomacy concept and activity, some American scholars tried to make another approach to diplomacy. Their approach then called multitrack diplomacy. This concept, actually, begin on the analogy when some blind people try to describe an elephant. On their description, the are describe an elephant in vary description. It is because they describe an elephant on the different side of it. These analogy then also using to enrich the concept of multitrack diplomacy, that in the implementation, some diplomatic activities seen uneffective so it is needed to be enhance. In the conflictual situation, the problem usually is so complext and complicated, so it is need for another actors with variative background to work together.

Begin of that problem, then, American scholars try tto make a new approach in the diplomacy activities related with the conflict resolution. Multitrack diplomacy is a concept that describe how the process of world peace on multi dimension view.

Multidimension means that on the process, involving many actors with different backgroud, they are interconnected each other, helping each other and united in the similar purpose, a world peace. So, multitrack diplomacy can be explained as conceptual framework which designed to describe many activities that contributed to the development of world peace (Diamond and McDonald, $1996: 1$ ).

Multitrack diplomacy concept is an enhance of the second-track diplomacy. Second track diplomacy, for the first time, launched by Joseph Montville in 1982. This concept used to explain the unformal and unofficial method on diplomacy done by govenrment and non government actors, even individu. Their diplomacy activities have three main purposes. They are to release or refuse the conflict among groups or nation state by focuse on communication, common understanding and relations; decreasing the tension, angry, fear or misunderstanding by humanizing the enemy and giving personal experience each other directly in the society; and influencing the way of thinking and action of the first track diplomacy by showing the root of the problem, feeling and need of options exploration without prejudgement, especially to establishing official diplomatic activity like negotiation or redevelop the policy. The main idea of second track diplomacy is that in the conflcit resolution, government or state can not walking alone, but it is need other actors which have knowledge, capabilities in many field related with the conflict.

The result of the enhancing fof second track diplomacy, then called multitrack diplomacy. Multitrack diplomacy have nine track activities done by government or non government actors. They are government (peacemaking trough diplomacy); non government or proffesional (peacemaking trough professional conflict resolution); business (peacemaking through commerce); private citizen (peacemaking trough personal involvement); research, training and education (peacemaking through learning); activism (peacemaking trough advocacy); religion (peacemaking trough faith in action); funding (peacemaking throgh providing resources); and communications and the media (peacemaking trough information) (Diamond and 
McDonalds, 1996 : 4-5).

In this articles, I will use the seventh track of diplomacy is religion. The discussion abouth these seventh track will be used to explain the role that can be plaed by ASEAN moslem community on conflict resolution in Southeast Asia region. Many religion groups in local, national, regional and international, are active on many effort and activity trough peacemaking process. They have similiar vission is creating the world peace. This vision developed by the norms and value which integrated on the belief system and the commitment for something like the spiritual truth of the interconnectedness of all life; social action; a prophetic imperative to seek justice, feed hungry, heal the sick and minister to the poor; equality and justice; forgiveness, concrition and reconciliation; practicing one's spriritual values in one's one life; community; hospitality; full and loving presence with the porr; the fostering of hope; living with an open, loving and compassionate heart; non violence and, insome case, pacifism; caretaking of ourselves, one another, and all precious beings; and service (Diamond and McDonalds, 1996).

The activities that played by the religion community is related with another track on multitrack diplomacy like public education, conference, research, discussion, mediation, dialogue project, comment in the media, protest, campaign, publication and other activities. These activities also done together with another religion community like interfaith dialoge where it is very important to exchange the opinion each other and build a networking and cooperation for conflict resolution. Interfaith dialogue can be played as informal conflict resolution or conciliation that before very difficult to do for the public. The concept which develope on the religion community, then, called transformational politics, a concousness or a view to the world shoud be change related with the change of the issues by time, and change of counciousness have to involving to the policy (Diamond dan McDonalds, 1996 : 97-100).

The position of the seventh track of multitrack diplomacyt is the center of multitrack diplomacy it self. Why? Because there are spiritual spirit, idealism and basic of ethic, that all of them as the basic of the people. Without heart and mind, it will difficult to accepting the goald of peace. The positive aspect of this track is it can be used to bring to the higher dimension on the understanding and feeling toward war and peace issues. The unity is a basic in the religion, showed in the love each other in diversity. But, we should also aware of negative side of this track while the religion conflict is begin on the different historical view that full of conflict and the view of truth and false in another side.

\section{ANALYSIS}

THE MAP OF CONFLICT RELATED WITH MOSLEM COMMUNITY IN SOUTHEAST ASIA

As describe before, there are two generalized problem of that can cause conflict involving moslem community in Southeast Asia region. The two generalized problems are politics and economics problems. Although both of them have specific case, but on reality, they are interconnected each other.

\section{a. Political Problems}

In the political problems related with moslem community in Southeast Asia, there are two problem characteristics. First, is the problems as legacy of the history related with identity and separatiem. As we know that almost all of Southeast Asia countries were colonialized by Western countries (except Thailand). One the impact of the colonialization is territory conflict. The people, who before have family or ethnich relations, have to separated each other because of the legacy of that colonialism. Their land have to devide into two state post independence. This problem can be found in Philipina, Thailand and Indonesia. As cultural, they have different culture and religion with the majority the people in their state. So, the change become minority, something that they never though before colonialism. This feeling, then, developing the spirit to separated with the state. So, actually, the main problem is politic, but, then, it change to religion conflict. The southern Thailand and southern 
Philipina, is unsolved well untill today (Gross, 2007)

\section{European Colonialism in Southeast Asia}

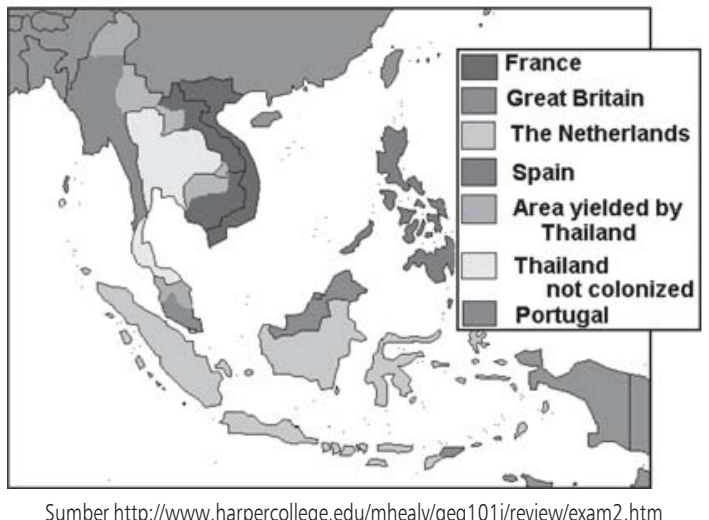

The second political characteristic problem is the problems related with the US policy on War on Terrorism. (Esposito, Boll and Bakar, 2008). As we know that, post 9/11 tragedy, there are some negative view toward moslem community in many countries. In other hand, Southeast Asia is the region which on its population, moslem is the majority and in some countries like Indonesia, Philipina and Thailand there were some terrorism activity. So, post 2001, moslem community in Southeast Asia, have got additional problem called terrorism. In the report of Centre for Strategic and International Studies (CSIS), United States in 2009, showed that almost all of the contributor mention that there are some problem in Southeast Asia and Australia related with radicalism, fundamentalism group etc. But the report also mention that the definition of terorrism it self, in the region, is still debatable, especially when it tried to be related with local violence in some countries in Southeast Asia (Borchgrave, Sanderson and Gordon, 2009). On another research by Suzaina Kadir from National University of Singapore, it found that post 9/11, moslim politics in Southeast Asia is going to be more complext and dynamic. It is influenced by globalization, Islamization and development. Moslem politics in Southeast Asia also very influenced by the interaction between state and the people or the relations of moslem community with the political regime of the state where they have lived. (Kadir, 2002).

\section{b. Economics Problems}

Another important problem beside the political problem is economics problem. World data viewed that in 2005 , there are 1,2 billion moslem people in the world. $60 \%$ of the population lived in Asia, while $30 \%$ of them live in Middle East and another live in other part of Asia especially in South and Southeast Asia. Indonesia have the first position of the largest moslem population or about 194 million, followed by India with 150 million peoples, Pakistan about 145 millions peoples and Bangladesh about 130 millions peoples. Another relative number is also in China, about 39 millions moslem people live there (Vaughn, 2005).

This number is not fix with the wealthy. There are many economic problem, especially poverty, face the moslem community in Southeat Asia region. The table showing the data about poor people who live in Southeast Asia countries. While we see in Indonesia, the number is large. So, it is need an improvement on moslem community economy. It is very important because the economic problem can create another problem like security and politics.

Table 1. The Number of Poor People in Southeast Asia (in Million) Poverty measurement under US\$

\section{$1.25 \mathrm{PPP}$}

\begin{tabular}{llllllll} 
TAHUN & INDONESIA & PHILIPINA & VIETNAM & CAMBODIA & LAOS & THAILAND MALAYSIA \\
\hline 2008 & 40,4 & 15,85 & 11,97 & 4,2 & 2,18 & 0,14 & 0,00 \\
2009 & 44,8 & 16,29 & 11,62 & 4,1 & 2,12 & 0,16 & 0,00 \\
2010 & 43,1 & 15,63 & 11,1 & 4,09 & 2,04 & 0,11 & 0,00 \\
\hline
\end{tabular}

Source : Asian Development Bank, 2011

\section{THE ROLES OF ASEAN MOSLEM COMMUNITY}

Relaed with the growth of ASEAN toward ASEAN Community2015, some problems still face, related with the readyness of the people it self. It can be a threat factor to the community it self. One of the basic factor is unstable in some filed, especially domestic conflict in member countries.

The problems related with moslem community in Southeast Asia still need to solved. So, it is need the special program or project to build peacemaking 
process. The ASEAN Moslem Community that will launch in the international conference on ASEAN moslem community is very important and strategic. It is important and strategic because this community can playing role as a place for discussion, meeting, research, action of the member to find suitable action for the conflict resolution especially in Thailand, Philipina and Myanmar.

There are some important roles that can be played by this community related with the track nine of multitrak diplomacy. They are:

1). Increasing solidarity and cooperation among moslem communities in ASEAN. We are realized that there are many moslem communities in every single members of ASEAN. So, with the community, it need more activities related with increasing solidarity and strengthening cooperationg each other. The community is the answer where moslem community can meet, work and act together, discussing the issues and find the solution.

2). Doing conflict resolution activities. Another program that can be played by the community is doing many activities related with conflict resolution. The first step is mapping the conflict it self. This mapping process is very important to classify many problems into the level of interest. It can be done by collaborative research by scholar from member countries. This research focus to find the root of the problem and potential of solution to be implemented. The last step is by the action and disemmination of the research result. It is also important because moslem people in ASEAN should to understand the real problem and what should they do.

On simple way, conflict resolution activities that can be done by the ASEAN moslem community is by action on three levels of conflict resolution, peace building, peace making ad peace keeping. Conflict resolution is an activity where both of the conflict person try to find the solution for the problem faced. This conflict esolution is a combination of real solution (tangible, or material solution) with the transformation of psichology and socialof the people in the conflict environment. The real solution is related with real change in the people daily life, while psychological change is the change of view to the conflict it self from the people to build trust and reconciliation. The golden goal is peace it self.

The implementation of conflict resolution are done in three level. They are peace building, peace making and peace keeping.Peace buildingis various activities related with the developing of peace. The activity done by seed or developing peace from the bottom. It is done by looking for the roots of the problem and the conflict resolutio from the peoplw point of view. So, the main porpuse of this level is how to build the feeling of the need to peace it self, from the people in the conflict. Related with the first level, ASEAN moslem community can playing roles by making an approach to the people. The purpose of this approach is to support the "peace want" feeling, that will be implemented on peace process.the community can playing role as a constructor to build the trust and "peace want" from the people.

The second level ispeace making. Afterthe people have the feeling to build peace, the next level is creating the peace building it self to be more concrete or real. Some activities that can be done is like held a meeting, conference and warkshop. The main purpose of this level is to find an agreement and commitment for the peace process. In this context, the community can be play by held some activities related with peace making like conference, interfaith dialogue, research related with conflict, making a progress repost of conflict resolution etc. The role that can be played by the community on this level is as mediator.

The last level is peace keeping. This proces done with the purpose to saving and keeping the peace process that have done by two levels before. The main task of this level is keep the process still on the rule, and making sure that peace can be implemented. Peace keeping activities, usually done post the agreement to make a strong commitment to 
keep peace together. The community can playng the roles like invole to the investigator team for the conflict, doing many activities to keeping peace post conflict like education, health service etc.

3). Keep the good relations with another ASEAN religion community. ASEAN religion community in welcoming ASEAN Community 2015 is not only done by moslem community but also by another religion. So, the ASEAN moslem community should to keep good relation and cooperation with them. This relation can be buil by common understanding, mutual trust, respect and based on humanity value and unity of ASEAN it self. I think that the community have to always make coordination with the ASEAN Secretariat and ASEAN Socio-Cultural Community's coordinator.

4). As the Center of Moslem Development in Southeast Asia. The establishment of ASEAN Moslem Community will not only as a place but also can contribute to the development of moslem community in Southeast Asia, especially in research. The community can playing role as center of research and development, and promotion of the moslem community in the region. Almost all of the participant of the first international conference on establishing ASEAN moslem community come from academic or sholars. It is showed that the role of scholar or intelectual group as epistemic community is very important. So, in the future, this community is also as research center for all of research related with moslem community in Southeast Asia. So, what is the relations with the conflict resolution process? The research that published to the people, will help to diseminating the information about the conflict it self and also the progress report. From this information, we hope that it will help to support the building of trust and understanding each other and also attracting people to involve actively on the peace process.

\section{CONCLUCION}

ASEAN Community 2015 promising ideal region where it will be very convinience place, full of peace, safe, wealth, respect each other and develop together. On the road map for this goal, a roadmap have been established by ASEAN leaders. But the implementation of the road map could not be done by government alone. It is need support and involvement of many peoples, groups, communitys and individuals. There are many problem that still could not be solved.

The ASEAN Moslem Community is one of the answer of the fearness of the implementation of ASEAN Community 2015. This community is not only as a place where many moslem meet from member sountries, but also playing as one of the solution machine of the problem faced by moslem community in Southeast Asia. the community can playing as the main actors as well as the seventh track diplomacy on conflict resolution.

The role for the conflict resolution is not only on surface, like discussion, annual meeting or conference, but also the real action for the conflict resolution process. But, this effort can be contraproductive while it is not managed well. So, the prequerement of the community roles are: (a) strong commitment of the member from ASEAN members countries to strugle for peace, using the principles of ASEAN Charter, like dialogue, avoiding violence and harmonious relations; (b) place it self as resolutor in the conflict resolution and always keeping independency on politics; (c) keep the good relations and make strong cooperation with another part of ASEAN, including secretariat office of ASEAN, three pillars of ASEAN Community, and another ASEAN religion community; (d) consistency on conflict resolution process in peace building, peace making andpeace keeping; (e) a commitment to publishing, diseminationg information and the research result, give the people peace education and all of activities supporting peace keeping process.

\section{REFERENCESS}

ASEAN Secretariat. 2010. Roadmap for an ASEAN Community 20092015: One Vision, One Identity, One Community. Jakarta: The ASEAN Secretariat.

Borchgrave, Arnauld de (ed). 2009. Conflict, Community and Criminality in Southeast Asia and Australia: Assessment from the 
field. Washington: CSIS.

Diamond, Louise dan John McDonald. 1996. Multitrack Diplomacy: A

System Approach to Peace. Connecticut: Kumarian Press.

Djelantik, Sukawarsini. 2008. Diplomasi Antara Teori dan Praktik.

Yogyakarta: Graha Ilmu.

Esposito, John L, John O Voll and Osman Bakar (eds). 2008. Asian Islam in 21st Century. Oxford: Oxford University Press.

Galtung, Johan,2003, Studi Perdamaian : Perdamaian dan Konflik Pembangunan dan Peradaban. Surabaya: Pustaka Eurika.

Gross, Max L. 2007. A Muslim Archipelago: Islam and Politics in Southeast Asia. Washington: NDIC Press.

ISEAS. 2008. The Asean Community: Unblocking the Roadblocks. Singapura: ISEAS.

Kadir, Suzaina. 2002. Mapping Moslem Politics in Southeast Asia After September 11. CERI.

Vaughn, Brush. 2005. Islam in South and Southeast Asia. CRS. 